\title{
WEATHERING CHARACTERISTICS OF IMPREGNATED AND COATED CALABRIAN PINE WOOD
}

\author{
Ergün Baysal \\ https://orcid.org/0000-0002-6299-2725
}

Hilmi Toker ${ }^{1}$

https://orcid.org/0000-0002-1900-9887

Türkay Türkoğlu ${ }^{2}$

https://orcid.org/0000-0003-2011-0410

Ahmet Gündüz ${ }^{1}$

https://orcid.org/0000-0001-5589-7167

Çă̆lar Altay ${ }^{3, \star}$

https://orcid.org/0000-0003-1286-8600

Mustafa Küçüktüvek ${ }^{4}$

https://orcid.org/0000-0002-5354-359X

Hüseyin Peker ${ }^{5}$

https://orcid.org/0000-0002-7771-6993

\begin{abstract}
This study was designed to investigate the weathering characteristics of Calabrian pine (Pinus brutia) wood. The wood specimens were impregnated with some copper-based chemicals and then varnish coated. As copper-based chemicals, Celcure C4, Korasit KS, and Tanalith E 8000 were used for impregnation. Polyurethane varnish (PV) and water-based varnish (WBV) were used as coating materials. Firstly, Calabrian pine wood was impregnated with $2,5 \%$ and $5 \%$ aqueous solutions of chemicals then coated with PV and WBV. Impregnated and coated Calabrian pine wood specimens were subjected to 6 months of natural weathering in Muğla, Turkey. After weathering, surface hardness, surface roughness, and adhesion strength changes of Calabrian pine wood specimens were determined. Impregnation caused to increase in surface hardness values of Calabrian pine. Surface hardness increases of WBV coated Calabrian pine specimens were higher than that of PV coated Calabrian pine specimens. Impregnation resulted in higher surface roughness values of Calabrian pine specimens. PV coated Calabrian pine specimens gave higher surface roughness than that of WBV coated Calabrian pine specimens. The adhesion strength values of all treatment groups were decreased after
\end{abstract}

\footnotetext{
${ }^{1}$ Muğla Sitkı Koçman University, Faculty of Technology, Department of Wood Science and Technology, Muğla, Turkey.

${ }^{2}$ Muğla Sttkı Koçman University, Köyceğiz Vocational School, Department of Forestry Muğla, Turkey.

${ }^{3}$ Aydın Adnan Menderes University, Aydın Vocational School, Department of Interior Design, Aydın, Turkey.

${ }^{4}$ Antalya Bilim University, Faculty of Fine Arts and Architecture, Department of Interior Architecture and Environmental Design, Antalya, Turkey.

${ }^{5}$ Artvin Çoruh University, Faculty of Forestry, Department of Forest Industry Engineering, Artvin, Turkey.

•Corresponding author: caglar.altay@adu.edu.tr
}

Received: 04.03.2020 Accepted: 27.01.2021 
weathering. In general, adhesion strength decreases of WBV coated Calabrian pine specimens were higher than that of PV coated Calabrian pine specimens. The concentration levels of chemicals did not have a significant effect on surface roughness and adhesion strength of Calabrian pine wood after weathering.

Keywords: Adhesion strength, Calabrian pine, impregnation, surface hardness, surface roughness, varnish, weathering performance.

\section{INTRODUCTION}

The wood material is a versatile natural resource for aesthetic, engineering, and structural applications. Due to its superior properties, wood material maintains its importance in the places of use and has approximately 10000 usage areas as raw material (Örs and Keskin 2001, Khalil et al. 2010). Like all biological organisms, the wood material does not remain resistant to outdoor climatic conditions (heat, light, moisture), mechanical influences (wind, sand), and the effects of biological pests for a long time. Therefore, it undergoes deformation and structural degradation (Budakçı and Atar 2001, Kılıç and Hafizoğlu 2007, Rowell 2005). The presence of special wood tissues such as anisotropic structure, texture, annual ring structure, sapwood, heartwood, reaction wood of wood material decays when exposed to long-term outdoor weather conditions (Bucur 2011). One of the most important and effective methods proposed to reduce or limit the deterioration of wood against such weather conditions is the impregnation of wood with chemicals (Temiz et al. 2005). The focus on copper-based preservatives has increased following concerns about the environmental effects of chromium and arsenic and resulting restrictions on the use of chromated copper arsenate (CCA) (Freeman and McIntyre 2008). It is generally known that new copper-based wood preservatives and varnishes retard or prevent photodegradation (Nejad and Cooper 2011). Copper forms certain complexes with wood components, such as copper-cellulose complexes, copper-lignin complexes, and crystalline or amorphous inorganic/organic copper compounds, and reduces the degradation of the wood surface from weathering factors (Temiz et al. 2005, Grelier et al. 2000). Zhang et al. (2009) determined the change in the surface characteristics of the wood impregnated with a copper-based chemical such as copper ethanolamine after the accelerated open weather test was largely prevented. Impregnation of wood with CCA (Copper chrome arsenic) and ACQ (Ammonium copper quat) provides high color stabilization in weathering conditions. Because of preventing lignification and carbonyl group formation, the process of impregnation with ACQ (Ammonium copper quat) slows down photodegradation on the wood surface (Temiz 2005).Also; wood surface applications such as impregnation and varnish should be investigated in terms of their effectiveness in weathering conditions and their compatibility with wood. Baysal et al. (2014) studied the effect of accelerated weathering on surface properties of Scots pine impregnated with some copper-containing chemicals such as Wolmanit-CB (copper/chromium /boron), Tanalith-E (TN-E), and Adolit-KD5 (AD-KD5) and coated with synthetic varnish and polyurethane varnish was investigated. According to the findings of their study, while weathering caused an increase in the hardness of impregnated and varnished specimens, the gloss of specimens decreased after weathering. Thus, modification techniques with impregnating materials can increase the resistance of the wood to weather conditions (Kamdem et al. 2002). Üstün (2019) determined the changes in physical properties of Scots pine (Pinus sylvestris L.) wood specimens which were treated with copper-based impregnation materials before varnishing. In his study, test specimens that were impregnated with a $2 \%$ aqueous solution of copper-based impregnation materials were then subjected to a varnishing process with polyurethane varnish and cellulosic varnish. The treated test specimens were exposed to natural weathering conditions for 6 months. At the end of this process, the color, gloss, surface hardness, and adhesion values of the test specimens were measured and their performance values were analyzed. According to the results of the study; the impregnated and varnished Scots pine wood specimens showed better physical properties except for adhesion resistance compared to the only varnished specimens. Scots pine wood covered with polyurethane varnish gave more positive results in terms of physical properties than the specimens coated with cellulosic varnish. Türkoğlu et al. (2015a) examined the color stability of Scots pine specimens impregnated with copper-containing chemicals such as Tanalith-E and Adolit KD- 5 before the coating of synthetic and polyurethane varnish after natural weathering. They stated that the color stability of impregnated and varnished wood specimens yielded better results than non-impregnated and only varnished wood specimens after natural weathering. Yalınkılıç et al. (1999) investigated the outdoor performance of Scots pine and chestnut wood treated with chromium-copper-boron (CCB) and applied with polyurethane varnish or alkyd-based synthetic varnish. They reported that CCB impregnation greatly stabilized the surface color of the wood. It was also claimed that preservative treatment followed by a surface coating system protected wood in long-term outdoor conditions. This study was carried out on 
Calabrian pine (Pinus brutia) wood specimens impregnated with 2,5 and 5 percent aqueous solutions of copper-based chemicals such as Celcure C4, Korasit KS, and Tanalith E 8000. After impregnation, PV and water-based varnish (WBV) were applied to the wood surface. Then, the wood specimens were exposed to 6 months of weathering. Therefore, the objective of this study was to investigate surface hardness, surface roughness, and adhesion strength changes of Calabrian pine specimens caused by weathering.

\section{MATERIALS AND METHODS}

\section{Preparation of test specimens}

Calabrian pine (Pinus brutia Ten) wood specimens were prepared in $10 \mathrm{~mm}$ x $100 \mathrm{~mm}$ x $150 \mathrm{~mm}$ (radial $\mathrm{x}$ tangent $\mathrm{x}$ longitudinal) dimensions. The test specimens were kept in the conditioning room for two weeks in order to $12 \%$ moisture content.

\section{Impregnation procedure}

In this study, the impregnation of test specimens was made by ASTM D1413-76 (1976) standard. 2,5\% and $5 \%$ aqueous solution of Celcure C4, Korasit KS and Tanalith E 8000 were used as impregnating agents. Celcure C4 contains $30 \%$ - $50 \%$ 2-aminoethanol, $10 \%$ - $30 \%$ copper carbonate, $<5 \%$ benzylammonium chloride and $<5 \%$ cyproconazol (Senkron 2020). Korasit KS contains 15,2 \% copper hydroxide carbonate, $8,4 \%$ N, N-Didecyi-N-methyl-poly (oxethyl) ammonium propionate (Varkim 2020). Tanalith E 8000 contains $14,55 \% \mathrm{~m} / \mathrm{m}$ copper hydroxide carbonate, $8 \% \mathrm{~m} / \mathrm{m}$ copper, $0,16 \% \mathrm{~m} / \mathrm{m}$ propiconazole and $0,16 \% \mathrm{~m} / \mathrm{m}$ tebuconazole (Hemel 2020). The test specimens were first exposed to a vacuum of $760 \mathrm{~mm} \mathrm{Hg}^{-1}$ for 30 minutes in the impregnation process. Then, the vacuum was terminated and the impregnation solution was allowed to diffuse under the influence of open-air pressure for 30 minutes. The retention amount of the test specimens at the end of the impregnation was calculated by the following formula Equation 1:

$$
\text { Retention }\left(\mathrm{kg} / \mathrm{m}^{3}\right)=\frac{G \times C}{100 \times V}
$$

\footnotetext{
Where: $\mathrm{G}=\mathrm{T}_{2}-\mathrm{T}_{1}$

$\mathrm{T}_{1}$ : First weight of the specimen $(\mathrm{kg})$

$\mathrm{T}_{2}$ : Final weight of the specimen $(\mathrm{kg})$

$\mathrm{V}$ : Volume of the specimen $\left(\mathrm{m}^{3}\right)$

C: Concentration (\%)
}

\section{Application of varnish}

It is important to prepare the wood surface for the experiments. Before applying the varnish, the surfaces were cleaned from dust with the proper sanding process. Polyurethane and water-based varnishes were used in this study. While the percentage of solids for the composition of polyurethane is $38 \%$, the water-based varnish contains 43,26\% (Tekno Marin 2020). According to ASTM D3023-98 (2017), a spray gun and varnish were applied to all surfaces and edges of Calabrian pine wood specimens. After the varnish was thoroughly mixed, it was thinned by adding thinner and two cross layers were applied to test specimen surfaces. Then, wood specimens were sanded with 220 numbered sand and topcoat application was started. In water-based varnish application, after sanding wooden surfaces with 220 grit sandpaper, the varnish was placed in an empty container and applied with a brush to all surfaces and edges of the wood. During the varnish application, the varnish was not diluted and applied in 2 layers. During the filling and topcoat application process, polyurethane and water-based varnish applied $100 \mathrm{~g} / \mathrm{m}^{2}$ for each application. 


\section{Surface hardness test}

The surface hardness test was made using the pendulum hardness tester according to the König measurement method and following the principles specified in ASTM D4366 (2016). Wood specimens were placed on the panel table, and a pendulum was placed on the panel surface. Then, the pendulum was deflected through $6^{\circ}$ and released, at the same time, a stopwatch was started. The time for the amplitude to decrease from $6^{\circ}$ to $3^{\circ}$ was measured as König hardness. The approximate moisture content of the wood specimens was $12 \%$ before the test. Ten replicates were made for each treatment group. Surface hardness measurements were made in parallel to the fibers.

\section{Surface roughness test}

In surface roughness measurements ten-point roughness average value $\left(\mathrm{R}_{\mathrm{z}}\right)$ was used. Roughness is defined as very small and periodically repeated irregularities other than the shape and fluctuations that occur on the surface of the material after application. Within the scope of the study, surface roughness measurements, Mitutoyo SURFTEST SJ-301 model has been made with needle scanning surface roughness measuring device. Roughness measurement; It has been made with the help of a suitable measuring mold in order to be able to measure from $12 \%$ humidity and always from the same area. Ten replicates were made for each treatment group. Surface roughness measurements were made in parallel to the fibers.

\section{Adhesion strength test}

The adhesion strengths of the specimens were determined according to ASTM D4541 (2017) and ISO 4624 (2016). In the determination of adhesion strength, $20 \mathrm{~mm}$ diameter test rollers were bonded to the surfaces of the specimens coated with protective layers at room temperature $\left(20^{\circ} \mathrm{C} \pm 2{ }^{\circ} \mathrm{C}\right)$ with the help of a mold. The specimens were then allowed to dry for 24 hours. The tester used to measure the adhesion resistance was set at a feed rate of $5 \mathrm{~mm}$ per minute. Adhesion strength was calculated according to the following formula $\left(\mathrm{MPa}=1 \mathrm{~N} / \mathrm{mm}^{2}\right)$ (Equation 2):

$$
\text { Adhesion strength }(X)\left(\frac{N}{m m^{2}}\right)
$$

Where:

$$
\begin{aligned}
& X=4 \mathrm{~F} / \pi \cdot \mathrm{d}^{2} \\
& \mathrm{~F}=\text { Force at break (Newton) } \\
& \mathrm{d}=\text { Diameter of test cylinder }(\mathrm{mm})
\end{aligned}
$$

The approximate moisture content of the wood specimens was $12 \%$ before the test. Ten replicates were made for each treatment group.

\section{Weathering test}

Calabrian pine wood specimens were exposed to weathering for 6 months from May 2019 to November. The wood panels were prepared for weathering according to ASTM D358-55 (1970). A test site has been established for practical evaluations near Muğla Regional Meteorological Observation Station in the South Aegean Region. The meteorological data of Muğla is provided in Table 1. 
Table 1: Meteorological data of Muğla.

\begin{tabular}{|c|c|c|c|c|c|c|}
\hline Mugla & May & June & July & August & September & October \\
\hline Minimum temperature per month $\left({ }^{0} \mathrm{C}\right)$ & 6,3 & 9,6 & 14,7 & 17,5 & 9,9 & 5,7 \\
\hline Average temperature per month $\left({ }^{0} \mathrm{C}\right)$ & 18,4 & 23,4 & 26,1 & 27,8 & 22,6 & 18,0 \\
\hline Maximum temperature per month $\left({ }^{0} \mathrm{C}\right)$ & 33,6 & 36,6 & 37,5 & 39,4 & 34,3 & 31,3 \\
\hline Minimum humidity per month $(\%)$ & 11,0 & 16,0 & 11,0 & 11,0 & 11,0 & 19,0 \\
\hline Average humidity per month $(\%)$ & 54,4 & 55,4 & 42,7 & 40,0 & 53,3 & 65,1 \\
\hline Maximum humidity per month $(\%)$ & 96,0 & 97,0 & 97,0 & 91,0 & 97,0 & 98,0 \\
\hline Maximum wind speed per month $(\mathrm{m} / \mathrm{sn})$ & 8,7 & 12,3 & 10,8 & 10,3 & 15,9 & 7,2 \\
\hline Average wind speed per month $(\mathrm{m} / \mathrm{sn})$ & 1,3 & 1,4 & 1,8 & 1,7 & 1,4 & 0,9 \\
\hline Total rainfall per month (mm=kg/m $\left.{ }^{-2}\right)$ & 9,0 & 76,5 & 43,2 & 16,4 & 51,4 & 78,6 \\
\hline Number of rainy days & 5 & 12 & 1 & 1 & 5 & 5 \\
\hline
\end{tabular}

\section{Statistical evaluations of test results}

Test results were analyzed by a computerized SPSS statistical program include analysis of variance and Duncan test applied at $95 \%$ confidence level. Statistical evaluations were made on homogeneity groups (HG) where different letters reflected statistical significance.

\section{RESULTS AND DISCUSSION}

\section{Surface hardness}

The retention and surface hardness values of Calabrian pine before and after 6 months of weathering are given in Table 2.

Table 2: Retention and surface hardness values of Calabrian pine specimens before and after weathering.

\begin{tabular}{|c|c|c|c|c|c|c|c|c|}
\hline \multirow[t]{2}{*}{ Impregnation+Varnish } & \multirow[t]{2}{*}{$\begin{array}{c}\text { Concentration } \\
(\%)\end{array}$} & \multirow[t]{2}{*}{$\begin{array}{l}\text { Retention } \\
\left(\mathrm{kg} / \mathrm{m}^{3}\right)\end{array}$} & \multicolumn{2}{|c|}{$\begin{array}{c}\text { Surface hardness } \\
\text { values of Calabrian } \\
\text { pine before } \\
\text { weathering }\end{array}$} & \multicolumn{2}{|c|}{$\begin{array}{c}\text { Surface hardness } \\
\text { values of Calabrian } \\
\text { pine after } 6 \text { months } \\
\text { of wethering }\end{array}$} & \multirow[t]{2}{*}{$\begin{array}{c}\text { Change } \\
(\%)\end{array}$} & \multirow[t]{2}{*}{$\begin{array}{l}\text { Homogeneity } \\
\text { groups }\end{array}$} \\
\hline & & & Mean & $\begin{array}{l}\text { Standard } \\
\text { deviation }\end{array}$ & Mean & $\begin{array}{l}\text { Standard } \\
\text { deviation }\end{array}$ & & \\
\hline PV & - & - & 78,00 & 9,38 & 86,80 & 7,75 & 11,28 & $\mathrm{E}$ \\
\hline WBV & - & - & 28,60 & 4,84 & 45,00 & 5,14 & 57,34 & $\mathrm{~A}$ \\
\hline Celcure C4+PV & 2,5 & 13,48 & 83,30 & 10,52 & 97,75 & 7,93 & 17,34 & $\mathrm{D}$ \\
\hline Celcure C4+PV & 5,0 & 30,92 & 115,0 & 13,10 & 113,71 & 10,71 & $-1,12$ & FG \\
\hline Korasit KS+ PV & 2,5 & 14,88 & 90,60 & 6,85 & 113,5 & 9,06 & 25,27 & $\mathrm{C}$ \\
\hline Korasit KS+ PV & 5,0 & 32,11 & 120,20 & 5,89 & 113,0 & 11,89 & $-5,99$ & G \\
\hline Tanalith E $8000+\mathrm{PV}$ & 2,5 & 15,05 & 115,2 & 9,22 & 114,8 & 12,69 & $-0,34$ & $\mathrm{~F}$ \\
\hline Tanalith E $8000+\mathrm{PV}$ & 5,0 & 31,47 & 110,8 & 14,20 & 108,6 & 9,47 & $-1,98$ & FG \\
\hline Celcure C4+ WBV & 2,5 & 13,48 & 28,60 & 5,58 & 42,00 & 4,57 & 46,85 & B \\
\hline Celcure C4+ WBV & 5,0 & 30,92 & 30,40 & 6,41 & 37,25 & 5,17 & 22,53 & $\mathrm{C}$ \\
\hline Korasit KS+ WBV & 2,5 & 14,88 & 30,40 & 11,38 & 33,57 & 5,64 & 10,42 & E \\
\hline Korasit KS+ WBV & 5,0 & 32,11 & 33,80 & 14,77 & 43,14 & 11,03 & 27,63 & $\mathrm{C}$ \\
\hline Tanalith E $8000+$ WBV & 2,5 & 15,05 & 30,80 & 7,94 & 46,50 & 7,12 & 50,97 & B \\
\hline Tanalith E $8000+$ WBV & 5,0 & 31,47 & 31,40 & 8,59 & 46,25 & 6,65 & 47,29 & B \\
\hline
\end{tabular}

Results reflect the average of 10 wood specimens. PV: Polyurethane varnish; WBV: Water-based varnish.

While the highest hardness value $(120,20)$ was found with $5 \%$ Korasit KS + PV treatment, the lowest hardness value $(28,60)$ was measured with $2,5 \%$ Celcure C4+WBV and only WBV treatments for Calabrian pine. Impregnation prior to varnishing resulted in an increase surface hardness values of the Calabrian pine test specimens before weathering. Because, while the surface hardness value of only PV coated Calabrian pine was 78 it was changed from 83,30 to 120,20 for impregnated and PV coated Calabrian pine. Moreover, the surface hardness value was 28,6 for only WBV coated Calabrian pine, it was changed from 28,60 to 33,80 for impregnated and WBV coated Calabrian pine. Gündüz et al. (2019) examined the hardness values of the wood impregnated with copper-based chemicals and then coated with water-based varnish after accelerated weathering. They found that copper-based pre-impregnation before WBV coating resulted in a slight de- 
crease in the surface hardness of the Scots pine wood before accelerated weathering exposure. In another study, Gündüz et al. (2020) studied the hardness values of the impregnated and PV coated Scots pine before accelerated weathering. According to the results, they found that the hardness values of the PV coated Scots pine increased with the impregnation process before weathering. While our results for WBV coated Calabrian pine are not similar to Gündüz et al. (2019), our results for PV coated Calabrian pine are in good agreement with the data Gündüz et al. (2020). According to our results, the hardness values of the PV coated Calabrian pine specimens were higher compared to the WBV coated Calabrian pine specimens before weathering. Except for $5 \%$ Celcure C4 + PV, $5 \%$ Corasite KS + PV, $5 \%$ Tanalith E $8000+$ PV and 2,5 \% Tanalith E 8000 + PV treatment groups, surface hardness values of all treatment groups were increased after weathering. Our results showed that the highest surface hardness increase $(57,34 \%)$ was obtained only WBV coated Calabrian pine specimens after weathering. WBV coated Calabrian pine specimens showed higher surface hardness values than PV coated Calabrian pine specimens after weathering. Baysal (2008) found that PV coating together with CCB impregnation hardened the wood surfaces after 3 months of outdoor weathering. This was because the impregnation materials increased hardness and wood specimens had a harder varnish layer (Keskin et al. 2011). Yalınkılıç et al. (1999) reported that impregnated and varnished wood surface, upon weathering, hardened markedly up to a point and then underwent a stable phase or gradual softening. After six months of weathering, the surface hardness of all untreated (control), and impregnated and coated wood specimens dramatically decreased. The decline was 74,34\% for untreated (control) Scots pine and 85,45\% for untreated (control) Oriental beech. Türkoğlu et al. (2015b) examined the surface hardness of wood material after natural weathering. Wood specimens were impregnated wood with Tanalith-E (TN-E), Adolit-KD 5 (ADKD 5), chromated copper arsenate (CCA). Then the wood material was coated with polyurethane varnish (PV). According to their results, after 3 months of natural weathering, showed that while surface hardness values of solely varnish coated, and both impregnated and varnish coated wood specimens increased, surface hardness of untreated (control) specimens decreased. However, surface hardness values of untreated (control), and impregnated and coated wood specimens decreased considerably after 6 months of natural weathering. After six months of natural weathering, the surface hardness loss of Scots pine and Oriental beech was the lowest in the TN-E impregnated and PV coated wood specimens. Baysal et al. (2014) investigated that the effect of accelerated weathering on surface properties of Scots pine impregnated with Wolmanit-CB, Tanalith-E (TNE), and Adolit-KD5 (AD-KD5) and coated with polyurethane varnish was investigated. According to the findings of their study, weathering caused an increase in the hardness of impregnated and varnished specimens after weathering. A similar surface hardness of Calabrian pine wood treated with boron and varnished with synthetic or polyurethane was also observed Toker et al. (2009). Results of our study similar to Yalınkılıç et al. (1999), Türkoğlu et al. (2015b), Baysal et al. (2014), and Toker et al. (2009).

\section{Surface roughness}

Table 3 shows the surface roughness values of Calabrian pine before and after 6 months of weathering.

Table 3: Surface roughness values of Calabrian pine wood specimens before and after weathering.

\begin{tabular}{|c|c|c|c|c|c|c|c|}
\hline \multirow[t]{2}{*}{ Impregnation+Varnish } & \multirow[t]{2}{*}{$\begin{array}{c}\text { Concentration } \\
(\%)\end{array}$} & \multicolumn{2}{|c|}{$\begin{array}{c}\text { Surface roughness } \\
\text { values of Calabrian } \\
\text { pine before } \\
\text { weathering } \\
(R z)\end{array}$} & \multicolumn{2}{|c|}{$\begin{array}{c}\text { Surface roughness } \\
\text { values of } \\
\text { Calabrian pine } \\
\text { after weathering } \\
(R z)\end{array}$} & \multirow[t]{2}{*}{$\begin{array}{c}\text { Change } \\
(\%) \\
(\mathrm{Rz})\end{array}$} & \multirow[t]{2}{*}{$\begin{array}{c}\text { Homogeneity } \\
\text { groups }\end{array}$} \\
\hline & & Mean & $\begin{array}{l}\text { Standard } \\
\text { deviation }\end{array}$ & Mean & $\begin{array}{l}\text { Standard } \\
\text { deviation }\end{array}$ & & \\
\hline PV & - & 0,37 & 0,13 & 1,50 & 0,20 & 305,40 & $\mathrm{AB}$ \\
\hline WBV & - & 4,17 & 0,94 & 5,45 & 0,68 & 30,69 & $\mathrm{E}$ \\
\hline Celcure C4+PV & 2,5 & 0,42 & 0,11 & 1,87 & 0,41 & 345,23 & $\mathrm{~A}$ \\
\hline Celcure C4+PV & 5,0 & 0,46 & 0,13 & 2,00 & 0,49 & 334,78 & A \\
\hline Korasit KS+ PV & 2,5 & 0,58 & 0,17 & 2,08 & 0,65 & 258,62 & $\mathrm{C}$ \\
\hline Korasit KS+ PV & 5,0 & 0,51 & 0,18 & 1,96 & 0,59 & 284,31 & $\mathrm{BC}$ \\
\hline Tanalith E $8000+\mathrm{PV}$ & 2,5 & 0,55 & 0,13 & 2,14 & 0,64 & 289,09 & $\mathrm{BC}$ \\
\hline Tanalith E $8000+\mathrm{PV}$ & 5,0 & 0,47 & 0,14 & 2,07 & 0,53 & 340,42 & $\mathrm{~A}$ \\
\hline Celcure C4+ WBV & 2,5 & 2,76 & 0,69 & 5,43 & 0,89 & 96,73 & $\mathrm{D}$ \\
\hline Celcure C4+ WBV & 5,0 & 4,01 & 1,39 & 4,93 & 0,66 & 22,94 & $\mathrm{E}$ \\
\hline Korasit KS+ WBV & 2,5 & 3,38 & 0,55 & 5,09 & 1,48 & 50,59 & $\mathrm{E}$ \\
\hline Korasit KS+ WBV & 5,0 & 4,44 & 0,17 & 5,59 & 1,09 & 25,90 & $E$ \\
\hline Tanalith E $8000+$ WBV & 2,5 & 3,42 & 0,90 & 5,07 & 0,86 & 48,24 & $\mathrm{E}$ \\
\hline Tanalith E $8000+$ WBV & 5,0 & 3,23 & 0,74 & 5,13 & 1,45 & 58,82 & $\mathrm{E}$ \\
\hline
\end{tabular}

Results reflect the average of 10 wood specimens. PV: Polyurethane varnish; WBV: Water-based varnish. 
When Table 3 is examined, while the highest $R z$ value $(4,44)$ was obtained with $5 \%$ Korasit KS+WBV treatment, the lowest $R z$ roughness value $(0,37)$ was measured with only PV coated Calabrian pine specimens. WBV coated Calabrian pine specimens gave higher surface roughness values than PV coated Calabrian pine specimens before weathering. Our results showed that impregnation with copper-based chemicals before PV coating caused to increase in $R z$ values of Calabrian pine specimens. In contrast, except for $5 \%$ Korasit KS + WBV treatment, $R z$ values of Calabrian pine were decreased for impregnated and WBV coated Calabrian pine. Gündüz (2018) investigated the surface roughness values of copper-based chemicals impregnated and water-based varnish (WBV) coated Scots pine. They found that pre-impregnation with chemicals before WBV coating caused to decrease in surface roughness values of Scots pine. Our results are in good agreement with the data Gündüz (2018). It was found that the concentration levels of chemicals did not have a significant effect on surface roughness. After natural weathering, while the highest $R z$ increase $(345,23 \%)$ was obtained with $2,5 \%$ Celcure C4+PV treatment, the lowest $R z$ increase $(22,94 \%)$ was obtained with $5 \%$ Celcure C4+WBV treatment. Our results showed that the WBV process has more positive results in preserving surface roughness than the PV process. Because, while $R z$ increases changed from 258,62 \% to 345,23 \% for impregnated and PV coated Calabrian pine, it changed from $22,94 \%$ to $96,73 \%$ for impregnated and WBV coated Calabrian pine after weathering. Pre-impregnation with chemicals before both varnish have no significant effect on the surface roughness of Calabrian pine after weathering.

\section{Adhesion strength}

The adhesion strength values of Calabrian pine specimens before and after 6 months are given in Table 4 .

Table 4: Adhesion strength values of Calabrian pine before and after weathering.

\begin{tabular}{|c|c|c|c|c|c|c|c|}
\hline Impregnation+Varnish & $\begin{array}{c}\text { Concentration } \\
(\%)\end{array}$ & \multicolumn{2}{|c|}{$\begin{array}{c}\text { Adhesion strength } \\
\text { values of Calabrian } \\
\text { pine before } \\
\text { weathering }\end{array}$} & \multicolumn{2}{c|}{$\begin{array}{c}\text { Adhesion strength } \\
\text { values after } \\
\text { weathering }\end{array}$} & $\begin{array}{c}\text { Change } \\
(\%)\end{array}$ & $\begin{array}{c}\text { Homogeneity } \\
\text { groups }\end{array}$ \\
\hline & & $\begin{array}{c}\text { Mean } \\
(\mathrm{MPa})\end{array}$ & $\begin{array}{c}\text { Standard } \\
\text { deviation }\end{array}$ & $\begin{array}{c}\text { Mean } \\
(\mathrm{MPa})\end{array}$ & $\begin{array}{c}\text { Standard } \\
\text { deviation }\end{array}$ & & \\
\hline PV & - & 3,47 & 0,48 & 3,28 & 0,71 & $-5,47$ & AB \\
\hline WBV & - & 2,83 & 0,54 & 1,59 & 0,32 & $-43,81$ & J \\
\hline Celcure C4+PV & 2,5 & 3,75 & 0,59 & 2,74 & 0,61 & $-26,93$ & H \\
\hline Celcure C4+PV & 5,0 & 3,06 & 0,39 & 2,95 & 0,46 & $-3,59$ & A \\
\hline Korasit KS+PV & 2,5 & 3,19 & 0,50 & 3,09 & 0,73 & $-3,13$ & A \\
\hline Korasit KS+PV & 5,0 & 3,32 & 0,59 & 2,91 & 0,48 & $-12,34$ & CD \\
\hline Tanalith E 8000+PV & 2,5 & 3,59 & 0,21 & 3,15 & 0,60 & $-12,25$ & CD \\
\hline Tanalith E 8000+PV & 5,0 & 3,41 & 0,57 & 3,12 & 0,74 & $-8,50$ & BC \\
\hline Celcure C4+ WBV & 2,5 & 2,55 & 0,33 & 1,92 & 0,38 & $-24,70$ & GH \\
\hline Celcure C4+ WBV & 5,0 & 3,00 & 0,28 & 2,44 & 0,57 & $-18,66$ & EF \\
\hline Korasit KS+ WBV & 2,5 & 2,52 & 0,47 & 1,96 & 0,31 & $-22,22$ & FG \\
\hline Korasit KS+ WBV & 5,0 & 2,97 & 0,41 & 2,17 & 0,38 & $-26,93$ & H \\
\hline Tanalith E 8000+ WBV & 2,5 & 2,97 & 0,38 & 2,52 & 0,56 & $-15,15$ & DE \\
\hline Tanalith E 8000+ WBV & 5,0 & 2,75 & 0,77 & 1,73 & 0,30 & $-37,09$ & I \\
\hline
\end{tabular}

Results reflect the average of 10 wood specimens. PV: Polyurethane varnish; WBV: Water-based varnish.

The highest adhesion strength value $(3,75 \mathrm{MPa})$ was obtained with 2,5\% Celcure C4+PV treatments for Calabrian pine specimens, the lowest adhesion strength value $\left(2,52 \mathrm{Nt} / \mathrm{mm}^{2}\right)$ was found with $2,5 \%$ Korasit KS+WBV for Calabrian pine before natural weathering. Our results showed that pre-impregnation with chemicals before varnish coating has no significant effect on the adhesion strength of Calabrian pine. However, Üstün (2019) found that pre-impregnation with copper-based chemicals caused to decrease in adhesion strength of Scots pine. Our results showed that PV coated Calabrian pine specimens gave higher adhesion values than that of WBV coated Calabrian pine specimens before weathering. For example, while adhesion strength values change from $3,06 \mathrm{Nt} / \mathrm{mm}^{2}$ to $3,75 \mathrm{MPa}$ for impregnated and $\mathrm{PV}$ coated Calabrian pine, it changed from 2,52 MPa to 3,00 MPa for impregnated and WBV coated Calabrian pine. Yakın (2001) observed that when water-based varnishes were applied to different tree species by different methods, the adhesion strength values were lower than solvent-based varnishes. Budakçı (2003) reported that the adhesion resistance values of water-soluble varnishes prepared for furniture surfaces are lower than those of solvent-based poly- 
urethane and acrylic varnishes. Budakçı and Sönmez (2010) studied the cellulosic, polyurethane, acrylic and water-based varnishes that have been applied to wood surfaces in different layer thickness. The effect of wood type and layer thickness on adhesion resistance of varnishes was determined by a pull-off test. In the study, it was determined that the highest adhesion resistance was obtained in polyurethane and acrylic varnishes. Our results are in good agreement with these researchers' findings. Weathering caused to decrease in adhesion strength of all treatment groups. In this study, while the highest adhesion strength decrease $(-43,81 \%)$ was obtained by only WBV coated Calabrian pine specimens, the lowest adhesion strength decrease $(-3,13 \%)$ was determined by $2,5 \%$ Korasit KS+PV treatment. Üstün (2019) investigated the adhesion strength values of wood impregnated with copper-containing chemicals and varnished with polyurethane, synthetic and water-based varnishes after natural weathering. According to the results obtained, it has been observed that the adhesion strength values of all test specimens decreased after the natural weathering process. The findings obtained from our study were similar to that of Üstün (2019). Decreases in adhesion strength of impregnated and WBV coated Calabrian pine was higher than that of impregnated and PV coated Calabrian pine. For example, while adhesion strength decreases for all WBV treatments change to from $-15,15 \%$ to $-43,81 \%$, it changed from $-3,13 \%$ to $26,93 \%$ for all PV treatments after weathering. Our results showed that pre-impregnation with chemicals before WBV coating caused do decreases adhesion strength losses after weathering. Because, while adhesion strength loss was $-43,81 \%$ for only WBV coated Calabrian pine, it changed from $-15,15 \%$ to $-37,09$ $\%$ for impregnated and WBV coated Calabrian pine after weathering. Concentration levels of chemicals did not affect the adhesion strength of Calabrian pine specimens after weathering.

\section{CONCLUSIONS}

The surface hardness, surface roughness, and adhesion strength changes of Calabrian pine impregnated with some copper-based chemicals and coated with WBV and PV after weathering were investigated.

The surface hardness values of PV coated specimens were higher than WBV coated specimens. Chemical treatments before both varnish coating resulted in higher surface hardness values. WBV coated Calabrian pine appears to have higher surface hardness than PV coated Calabrian pine after weathering. WBV coated Calabrian pine gave higher surface roughness values than PV coated Calabrian pine before weathering. In contrast, PV coated Calabrian pine gave more roughness values than WBV coated Calabrian pine after weathering. In general, WBV coated Calabrian pine showed more positive results in preserving the surface roughness after weathering. According to the adhesion strength test results, PV coated Calabrian pine gave higher adhesion values than WBV coated Calabrian pine before weathering. The adhesion strength of all treatment groups was decreased after weathering. The adhesion strength decreases for WBV coated Calabrian pine specimens were higher than that of PV coated Calabrian pine specimens. Concentration levels of chemicals have no effects on surface roughness and adhesion strength.

\section{ACKNOWLEDGMENTS}

This study has been granted by the Muğla Sitkı Koçman University. The research project grant number is $(18 / 024)$. The project name is "Impregnation of wood before water based varnish coating for improving weathering durability". Project manager Ergun Baysal, project researchers Hilmi Toker, Ahmet Gunduz and Turkay Turkoglu. Mustafa Kucuktuvek, Caglar Altay and Huseyin Peker took part in the preparation of the article and the evaluation of the research results.

\section{REFERENCES}

ASTM. 1976. Standard Methods of Testing Wood Preservatives by Laboratory Soilblock Cultures. ASTM D1413-76. 1976. ASTM International: West Conshohocken’, PA, USA. https://www.astm.org/Standards/ D1413.htm

ASTM. 2016. Standard Test Methods for Hardness of Organic Coatings by Pendulum Test. ASTM D4366. 2016. ASTM International: West Conshohocken|, PA, USA. https://standards.globalspec.com/std/10151454/ ASTM\%20D4366 
ASTM. 2017. Standard Practice for Determination of Resistance of Factory Applied Coatings on Wood Products to Stains and Reagents. ASTM D3023-98. 2017. ASTM International: West Conshohocken!, PA, USA. https://www.astm.org/Standards/D3023.htm

ASTM. 1970. Standard specification for wood to be used panels in weathering tests of paints and varnishes. ASTM D358-55. 1970. ASTM International: West Conshohocken», PA, USA. https://www.astm.org

ASTM. 2017. Standard Test Method for Pull-off Strength of Coatings Using Portable Adhesion Testers. ASTM D4541.2017. ASTM International: West Conshohocken!, PA, USA. https://www.astm.org/Standards/ D4541.htm

Baysal, E. 2008. Some physical properties of varnish coated wood preimpregnated with copper chromated boron (CCB) after 3 months of weathering exposure in Southern Eagen Sea Region. Wood Res 53(1): 43-54. http://www.woodresearch.sk/wr/200801/04.pdf

Baysal, E.; Tomak, E.D.; Ozbey, M.; Altin, E. 2014. Surface properties of impregnated and varnished Scots pine wood after accelerated weathering. Color Technol 130(2): 140-146. https://doi.org/10.1111/ cote. 12070

Bucur, V. 2011. Delamination in wood, Wood products and wood-based composites. Springer Science \& Business Media: Berlin, Germany. https://doi.org/10.1121/1.3571423

Budakçı, M. 2003. Design and production of a new adhesion testing device and its utilization with testing of wood varnishes. Ph.D. Thesis, Gazi University Institute of Science, Ankara, Turkey, 178p (in Turkish).

Budakçı, M.; Atar, M. 2001. Effects of bleaching process on hardness and glossiness of pine wood (Pinus sylvestris L.) exposed to outdoor conditions. Turk J Agri For 25: 201-207. https://www.academia. edu/32388804/Effects_of_Bleaching_Process_on_Hardness_and_Glossiness_of_Pine_Wood_Pinus_sylvestris_L_._Exposed_to_0utdoor_Conditions

Budakçı, M.; Sönmez, A. 2010. Determining adhesion strength of some wood varnishes on different wood surfaces. GUJEAF 25(1): 111-118.

Freeman, M.H.; McIntyre, C.R. 2008. A comprehensive review of copper based wood: with a focus on new micronized or dispersed copper systems. For Prod J 58(11): 6-27.

Grelier, S.; Castellan, A.; Kamdem, D.P. 2000. Photo-protection of copper amine treated pine. Wood Fib Sci 32(2): 196-202. https://wfs.swst.org/index.php/wfs.

Gündüz, A.; Baysal, E.; Türkoğlu, T.; Küçüktüvek, M.; Altay, Ç.; Peker, H.; Toker, H. 2019. Accelerated weathering performance of Scots pine preimpregnated with copper based chemials before varnish coating. Part II: coated with water based varnish. Wood Res 64(6): 987-998. http://www.woodresearch.sk/ wr/201906/06.pdf

Gündüz, A.; Baysal, E.; Türkoğlu, T.; Altay, Ç.; Küçüktüvek, M.; Toker, H.; Peker, H. 2020. Accelerated weathering performance of Scots pine pre-impregnated with copper based chemials before varnish coating. Part I: coated with cellulosic and polyurethane varnish. Color Techol 136(1): 34-44. https://doi.org/10.1111/cote.12435

Gündüz, A. 2018. Determination of the effects of copper based chemicals on the performance of varnishes in accelerated- aging. Master Thesis, Muğla Sttkı Koçman University, Institute of Science, Muğla, Turkey, 108 $\mathrm{p}$ (in Turkish). bcs

Hemel. 2020. Tanalith E 8000. https://hemel.com.tr/tr/urunler/endustriyelemprenye/tanalith\#.X42AOoz-

Kamdem, D.P.; Pizzi, A.; Jermannaud, A. 2002. Durability of heat-treated wood. Holz Roh-Werks 60(1): 1-6. https://link.springer.com/content/pdf/10.1007/s00107-001-0261-1.pdf

Keskin, H.; Atar, M.; Korkut, S.; Korkut, D.S. 2011. Impact of impregnation with Imersol Aqua on the surface adhesion strength of synthetic, acrylic, polyurethane, and water-based varnishes. Pig Res Techol 40(3): 
154-160. https://doi.org/10.1108/03699421111130414

Khalil, H.P.S.A.; Bhat, I.H.; Awang, K.B.; Bakare, I.O.; Issam, A.M. 2010. Effect of weathering on physical, mechanical and morphological properties of chemically modified wood materials. Mater Des 31(9): 4363-4368. https://doi.org/10.1016/j.matdes.2010.03.045

Kılıç, A.; Hafizoğlu, H. 2007. Influences of weathering on chemical structure of wood and protection treatments. SDUFFJ (2): 175-183. http://acikerisim.isparta.edu.tr/xmlui/handle/123456789/3814

Nejad, M.; Cooper, P. 2011. Exterior wood coatings. Part-1: performance of semitransparent stains on preservative-treated wood. J Coat Technol 8(4): 449-458. https://doi.org/10.1007/s11998-011-9332-3

Örs, Y.; Keskin, H. 2001. Wood Technology. 1. Print, Nobel Academic Publishing: Ankara, Turkey. (in Turkish).

Rowell, R.M. 2005. Handbook of wood chemistry and wood composites. CRC Press: Florida, USA. https://www.crcpress.com/Handbook-of-Wood-Chemistry-and-Wood-Composites/Rowell/p/ book/9781439853801

Senkron. 2020. Naturewood. https://www.ahsap.com/urunler/emprenye/maddeler/naturewood.

Tekno Marin. 2020. Teknopox Epoxy Varnishes. http://www.teknomarin.com.tr/en/products/varnishes

Temiz, A. 2005. The effect of simulated weathering on preservative treated wood. Ph.D. Thesis, Karadeniz Technical University Institute of Science, Trabzon, Turkey, 228p (in Turkish).

Temiz, A.; Yıldız, Ü.C.; Aydın, İ.; Eikenes, M.; Alfredsen, G.; Çolakoğlu, G. 2005. Surface roughness and colour characteristics of wood treated with preservatives after accelerated weathering test. Appl Surf Sci 250(1-4): 35-42. https://doi.org/10.1016/j.apsusc.2004.12.019

Toker, H.; Baysal, E.; Kesik, H.İ. 2009. Surface characteristics of wood pre-impregnated with borates before varnish coating. For Prod J 59(7-8): 43-46. http://agris.fao.org/agris-search/search.do?recor$\mathrm{dID}=\mathrm{US} 201301690868$.

Türkoğlu, T.; Baysal, E.; Toker, H. 2015a. The effects of natural weathering on color stability of impregnated and varnished wood materials. Adv Mater Sci Eng Article ID 526570. https://doi.org/10.1155/2015/526570

Türkoğlu, T.; Baysal, E.; Küreli, I.; Toker, H.; Ergün, M.E. 2015b. The effects of natural weathering on hardness and gloss of impregnated and varnished Scots pine and Oriental beech wood. Wood Res 60(5): 833-844. http://www.woodresearch.sk/wr/201505/15.pdf

ISO. 2006. Paints and Varnishes-Pull-off Test for Adhesion. ISO 4624. 2006. London, United Kingdom. https://www.iso.org/obp/ui/\#iso:std:iso:4624:ed-3:v1:en

Üstün, S. 2019. Physical properties of Scots pine impregnated with copper based chemicals in weathering conditions and effects of impregnation with copper based chemicals before varnish coating on physical properties of Scots pine after natural weathering. Master Thesis, Muğla Sitkı Koçman University, Institute of Science, Muğla, Turkey, 78p (in Turkish).

Varkim. 2020. Emprenye Ürünleri. https://www.varkim.com.tr/?page_id=3044

Yakin, M. 2001. Effects of the resistance to adhesion, glossy and hardness at the waterborne varnishes, Master Thesis, Gazi University Institute of Science, Ankara, Turkey. 124p (in Turkish).

Yalınkılıç, M.K.; Imamura, Y.; Takahashi, M.; İlhan, R.; Yalınkılıç, A.C.; Demirci, Z. 1999. FTIR studies of the effects of outdoor exposure on varnish coated wood pretreated with CCB or water repellents. $J$ Coat Techol 71: 103-112. https://link.springer.com/content/pdf/10.1007/BF02697928.pdf

Zhang, J.; Kandem, D.P.; Temiz, A. 2009. Weathering of copper-amine treated wood. Appl Surf Sci 256: 842-846. https://doi.org/10.1016/j.apsusc.2009.08.071 